\title{
Life Cycle Impact Assessment on Electricity Production from Biomass Power Plant System Through Life Cycle Assessment (LCA) Method using Biomass from Palm Oil Mill in Indonesia
}

\author{
Kiman Siregar ${ }^{1 *}$, Achmadin Luthfi Machsun ${ }^{2}$, Sholihati Sholihati ${ }^{3}$, Rizal Alamsyah ${ }^{4}$, \\ Ichwana Ichwana ${ }^{1}$, Nobel Christian Siregar ${ }^{4}$, Syafriandi Syafriandi ${ }^{1}$, Intan Sofiah ${ }^{5}$, \\ Try Miharza ${ }^{6}$, Syukri Muhammad Nur ${ }^{7}$, Olga Anne ${ }^{8}$, and Roy Hendroko Setyobudi ${ }^{7,9}$ \\ ${ }^{1}$ Department of Agricultural Engineering of Syah Kuala University, \\ Jl. Tgk. Hasan Krueng Kalee, Banda Aceh 23111, Indonesia \\ ${ }^{2}$ PT. Enerba Teknologi, Jl. Tekno Widya Setu Tangerang Selatan, Banten, 15314, Indonesia \\ ${ }^{3}$ Department of Agricultural Industry Technology, Serambi Mekkah University, \\ Jl. Unmuha, Batoh Lueng Bata Banda Aceh 23245, Indonesia \\ ${ }^{4}$ Centre for Agro-Based Industry, Ministry of Industry Indonesia, Jl. Harsono, \\ Jakarta Selatan 12550, Indonesia \\ ${ }^{5}$ Dakara Bisnis Institute, Department of Environment, Jl. Lingkar Baru Laladon, \\ Dramaga Bogor, 16680, Indonesia \\ ${ }^{6}$ Indonesian Life Cycle Assessment Network (ILCAN), P2Kimia, Jl, Puspitek, LIPI, Serpong \\ Tangerang, 15314, Indonesia \\ ${ }^{7}$ Graduate School of Renewable Energy, Darma Persada University, Jl. Taman Malaka Selatan No.22, \\ Jakarta Timur, 13450, Indonesia \\ ${ }^{8}$ Engineering Department of Marine Technology and Natural Sciences Faculty, Klaipeda University, \\ H. Manto g. 84, Klaipèda 92294, Lithuania, EU \\ 7,9 Department of Agriculture Science, Postgraduate Program, University of Muhammadiyah Malang, \\ Jl. Raya Tlogomas No.246, Malang, 65145, Indonesia
}

\begin{abstract}
New energy and renewable widely available in Indonesia. One of them is the biomass that can be used with gasification technology. Biomass is an organic matter to which derived from biological materials. This research was used integration gasification system with a gas engine, which works more properly with $\mathrm{CO}$, and $\mathrm{H}_{2}$. The advantage of this biomass power plant compared the environmental impact on other types of plants such as coal-fired power plants, diesel power plants, etc. Therefore the potential of environmental impacts was generated, it is necessary to calculate quantitatively through the life cycle assessment methods. This research aimed to calculate impact assessment on electricity production from a Biomass Power Plant system through a life cycle assessment with boundary cradle to grave in Indonesia. The study revealed that greenhouse gas (GHG) emission of electricity production from an empty fruit bunch palm oil mill was $0.15 \mathrm{~kg} \mathrm{CO}_{2}$-eq $\mathrm{kWh}^{-1}$. The gas engine was the highest GHG emission contributor during its life cycle. Empty fruit bunch as a source of biomass for electricity production was considered as climatefriendly power plant system due to its potential in reducing GHG emission from palm oil production and released lower GHG emission.
\end{abstract}

Keywords: Greenhouse gas, gasification technology, renewable energy, waste to electricity.

\footnotetext{
* Corresponding author: ksiregar.tep@unsyiah.ac.id
} 


\section{Introduction}

Indonesia has a huge number of renewable energy sources, like biomass. Installed capacity power plants Indonesia now $53585 \mathrm{MW}$, where the potential energy biomass is the largest of renewable sources of energy that owned by Indonesia [1]. Biomass is organic matter to which derived from biological materials. Biomass is a potential energy resource and there are several pathways, such as physical, thermal, chemical and biological, to generate energy. Unlike fossil fuel, biomass as renewable fuel has an advantage in maintaining a closed carbon cycle with no net increase in atmospheric $\mathrm{CO}_{2}$ levels [2]. Biomass takes Carbon out of the atmosphere while it is growing and returns it as it is burned. The increase of $\mathrm{CO}_{2}$ emission from fossil fuels has a dominant influence on the atmospheric $\mathrm{CO}_{2}$ concentration that eventually results in rising global temperature and sea level [3]. Moreover, its negligible sulfur and nitrogen are the main advantages of using biomass for preventing acid rain [4].

There is the potential number of biomass produced from palm oil industry. The biomass from palm oil industry can be clasified into oil palm fronds (OPF), oil palm trunks (OPT), empty fruit bunch (EFB), palm kernel shells, mesocarp fibre and palm oil mill effluent (POME) [5]. The oil palm EFB is one of the high carbon content biomass, which is currently used as a combustion boiler fuel with very low efficiency. It contains cellulose, hemicellulose, and lignin, which have high carbon and hydrogen contents, comparable with hard wood [3]. In 2030, it was estimated that there would be a production of $54 \times 10^{6} \mathrm{t}$ of empty fruit bunch. However, this empty fruit bunch is rarely to be utilized and usually turns into a waste product or as a source of fertilizer. In order to reduce the waste capacity from an empty fruit bunch and to obtain the potential energy, this biomass from an empty fruit bunch should be utilized for electricity production through a biomass power plant system. Oil palm is also said as an emitter in all stages of its life, but the use of oil palm biomass can reduce the emissions produced. According to Shuit et al. combustion of oil palm biomass does not contribute to net amount of carbon in the atmosphere as carbon is assimilated during plant growth [6].

The utilization of an empty fruit bunch through a biomass power plant system can be conducted by using biomass gasification. Gasification is a thermo-chemical conversión of biomass into a valuable gaseous product [7]. The gasification of biomass allows the production of a biosynthesis gas or "bio-syngas", consisting primarily of $\mathrm{CO}, \mathrm{CO}_{2}, \mathrm{H}_{2}$, $\mathrm{CH} 4, \mathrm{~N}_{2}$, LHV and tar component [8]. It also produces solids (such as char, ash) and condensable products like tars and [9]. The process of gasification consisting of four stage of the process on the basis the difference range temperature conditions, which is drying $\left(\mathrm{T}>150{ }^{\circ} \mathrm{C}\right)$, pyrolysis $\left(150{ }^{\circ} \mathrm{C}<\mathrm{T}<700{ }^{\circ} \mathrm{C}\right)$, oxidation $\left(700{ }^{\circ} \mathrm{C}<\mathrm{T}<1500{ }^{\circ} \mathrm{C}\right)$, and the reduction $\left(800{ }^{\circ} \mathrm{C}<\mathrm{T}<1000{ }^{\circ} \mathrm{C}\right)$. The results of pyrolysis in the form of charcoal subjected to the process of combustion and a reduction process that generates a gas $\mathrm{H}_{2}$ and $\mathrm{CO}$ [7]. Proper gasification biomass can deliver energy for generating electricity as a source of renewable energy. One of the advantages of this biomass power plant is that it has a smaller environmental impact compared to other types of plants, such as coal-fired power plants, diesel power plants, and others. Therefore to ensure how much potential environmental impacts are generated, it is necessary to calculate quantitatively through the life cycle assessment method. This research aims to calculate impact assessment on electricity production from a biomass power plant system through a life cycle assessment with system through a life cycle assessment with system boundary cradle to grave in Indonesia. 


\section{Materials and methods}

\subsection{Research boundaries and assumptions}

This research is limited to these conditions:

i. This study is branded with a "cradle to grave" life cycle assessment, which is from material acquisition namely land preparation until electricity production through biomass power plant system to consumer (user) and the end-of-life.

ii. The data used for analysis within the range of seed preparation to harvesting is secondary data from numerous sources, which presents the typical in Aceh Province Indonesian oil palm plantation activity.

iii. The electricity production from empty fruit bunch from palm oil involve some processing activities namely a) land preparation, b) seedling, c) planting, d) fertilizing, e) protection, f) harvesting, g) palm oil mills h) biomass tank, i) reactor, j) cyclone, $\mathrm{k}$ ) wet scrubber, 1) filter $1, \mathrm{~m}$ ) blower, n) filter 2, o) gas engine, p) user and the end of life (Figure 1 shows flow chart analysis of empty fruit bunch biomass processing from palm oil cultivation as source for electricity production).

iv. Impact analysis is carried out to analyze greenhouse gas (GHG) emission based on life cycle assessment (LCA) method.

v. Most of all, data used in the life cycle inventory (LCI) is based on Aceh Province in Indonesia's condition.

vi. The functional unit (FU) of this study is $1 \mathrm{kWh}$.

vii. LCI analysis was performed based on data collected from oil palm plantation in Aceh Province, Indonesia.

viii. Transportation from seedling to plantation area and from plantation to palm oil mills was also considered.

ix. The distance of electricity production (biomass power plant system) to end-user assumed $2 \mathrm{~km}$ distribution away.

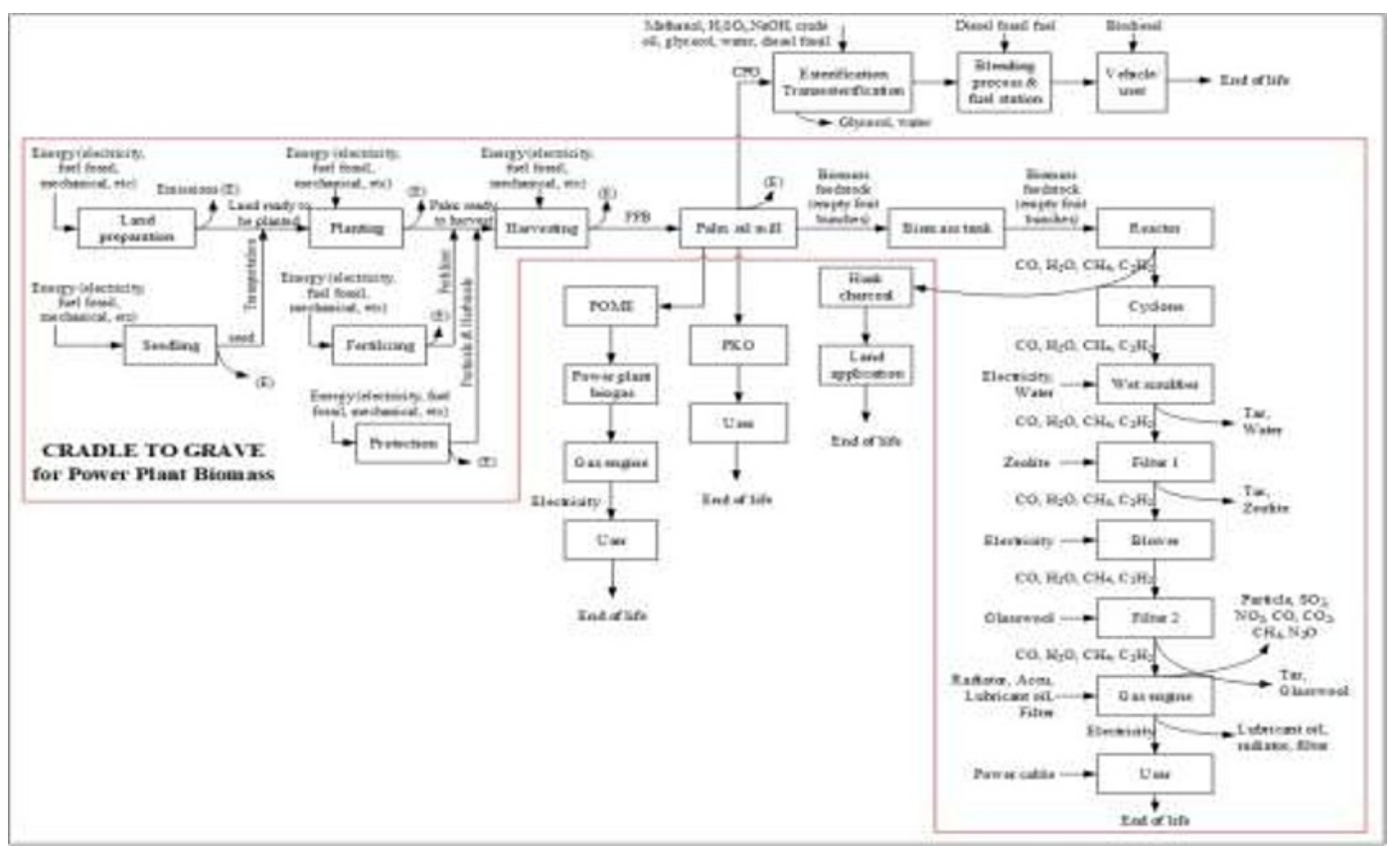

Fig. 1. The illustration of boundary condition for this study 


\subsection{Processing empty fruit bunch into gasifier}

Gasification of the oil palm EFB was carried out using reactor. The oil palm EFB feedstock was weighted and introduced into the reactor by inserting dried empty fruit bunch into the biomass tank. The amount of biomass inserted into the operation of generators for $8 \mathrm{~h}$. The water in full content has been prepared. Gasifier panel turned on, all turned water pump, ensure that water can circulate. Then the gas generators are ready, valve with a new source of gas to which the vote, and pressed the button to open the generator will be able to operate on the use of gas fuel gasifier. The detail gasification system is presented in Figure 2.

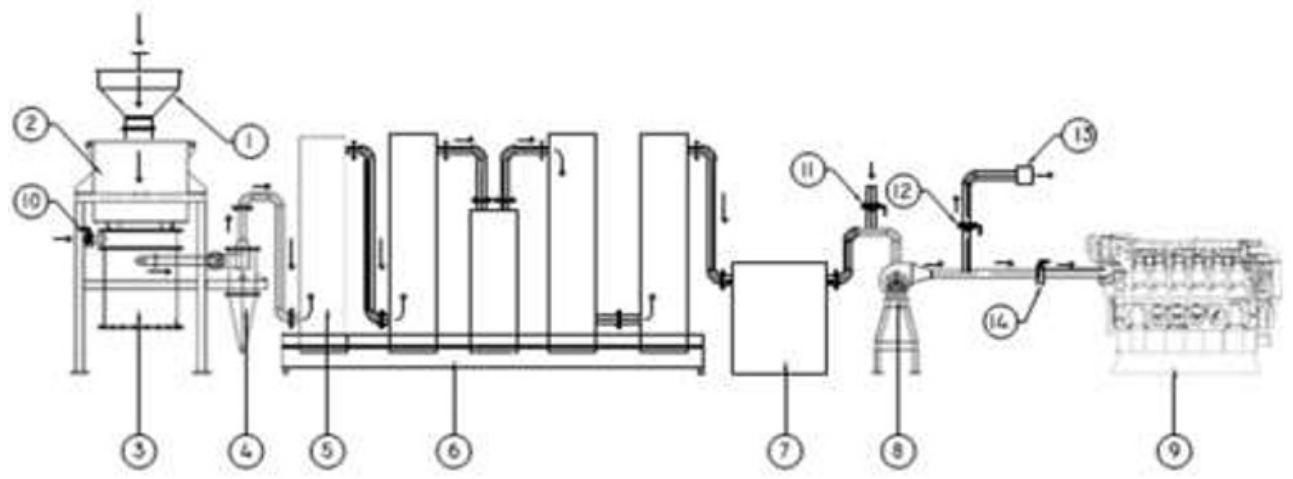

Fig. 2. The scheme of gasification system

Description: 1) Charging biomass tank, 2) Biomass tank, 3) Reactor, 4) Cyclone, 5) Wet scrubber, 6) Water tank, 7) Filter, 8) Blower, 9) Engine gas Genset with Cap.50 kW, 10) Air inlet nozzle (valve 1), 11) valve 2,12) Valve 3,13) Exhaust gas, 14) Valve 4.

The design type downdraft gasification for this study is a type of fixed-bed gasification with the direction of airflow from bottom to top. The advantages of this type of downdraft are not overly sensitive to tar and can easily adapt to the amount of biomass feed. Gases of combustion of this type of downdraft gasification work bypassed on the oxidation of combustion by means of flow pulled down so that the gas produced will be cleaner because the tar and oil will be burned.

\subsection{Source data and problem formulation}

Data used for analysis is collected in four methods, i.e.:

i. Survey to obtain related data of the object being studied, relevant sources, used parameter and others associated in the research.

ii. Literature study.

iii. Consultation and interview from a related authorized person including government agencies, private sector and academician.

iv. The direct measurement carried out in the laboratory and field.

v. The collecting data of primary data from PT.PN 1 Lhoksukon-East Aceh, and private company national in Aceh Province, i.e.: PT.SPS 1 and 2 in Nagan Raya, PT. Soxfindo in Nagan Raya, PT. Kurnia Tanah Subur in Meulaboh, PT.PKS in Biureun, and oil palm plantation from people, i.e., Nagan Raya Districts, West Aceh Districts, East Aceh Districts, Biureun Districts, and Lhokseumawe Districts. Secondary data which obtained from national and international journal, student field practice report on oil palm, undergraduate thesis, graduate thesis, relevant research report, and also publication released from national private plantation companies. 


\section{Results}

\subsection{Life cycle inventory, material, and energy consumption}

Starting from the quantity and source of empty fruit bunch which was collected from palm oil mill, the palm oil plantation material and energy to produce empty fruit bunch need to be investigated. Then, material and energy consumption during electricity production in the biomass power plant system also needs to be investigated afterward. The first step in the development of palm oil plantation is land preparation. Land preparation activities are usually conducted by the utilization of primary or secondary forest. Before planting, seedling activities were conducted during 12 mo which seed as the seedling source. Total of 136 trees $\mathrm{ha}^{-1}$ has been planted. In the development phase, various fertilizer compounds such as $\mathrm{N}, \mathrm{P}, \mathrm{K}, \mathrm{Mg}, \mathrm{B}$, and organic fertilizer as well as various plant pests has been applied in a very intensive way.

Palm oil trees start to produce after $30 \mathrm{mo}$, with the number of production was $8 \mathrm{t}$ seed $\mathrm{ha}^{-1}$. Crude Palm Oil (CPO) was produced in the palm oil mill as well as this stage also produces an empty fruit bunch which then was utilized as a source of biomass for electricity production. Fruit empty bunch inserted into the gasification system. Gasification of the oil palm EFB was carried out using a reactor and supported by a gas engine to produce biosynthesis gas. Electricity was used for wet tar scrubber and blower process stage. Glass wool and zeolite were used for the filtering process. Lead-acid battery, lubricant oil, coolant radiator, and filter were used for gas engine applications. Detail description of sixteen subprocesses involved in LCI for electricity production is shown in Table 1. Material and energy used for $1 \mathrm{kWh}$ from biomass power plants are shown in Table 2.

Table 1. The detail description of life cycle on electricity production from fruit empty bunch biomass from palm oil mill with boundary cradle to grave

\begin{tabular}{|c|c|c|}
\hline Input activities & Component & Oil palm \\
\hline \multirow{7}{*}{$\begin{array}{l}\text { (1) Land } \\
\text { preparation }\end{array}$} & Early land uses & Primer \& secondary forest \\
\hline & Soil fertility & Fertile \\
\hline & Tree, diameter $>60 \mathrm{~cm}$ & 26 trees $\mathrm{ha}^{-1}$ to 100 trees $\mathrm{ha}^{-1}$ \\
\hline & Tree, diameter $>30 \mathrm{~cm}$ & Approx. 2500 trees $\mathrm{ha}^{-1}$ \\
\hline & Coarse grass & 10 to 30 groups $\mathrm{m}^{-2}$ \\
\hline & Soil tillage & Effective soil depth $50 \mathrm{~cm}$ to $150 \mathrm{~cm}$ \\
\hline & Plant above the soil surface & Nuts \\
\hline \multirow[t]{2}{*}{ (2) Seedling } & Seedling time & $12 \mathrm{mo}$ \\
\hline & Seedling source & Seed \\
\hline \multirow[t]{3}{*}{ (3) Planting } & Plants width space & $9 \mathrm{~m} \times 9 \mathrm{~m} \times 9 \mathrm{~m}$ \\
\hline & Number of plants & $136 \mathrm{ha}^{-1}$ \\
\hline & Number of hole & $50 \mathrm{~m} \times 40 \mathrm{~m} \times 40 \mathrm{~cm}$ \\
\hline \multirow{2}{*}{ (4) Fertilizing } & Fertilizer compound & $\mathrm{N}, \mathrm{P}, \mathrm{K}, \mathrm{Mg}, \mathrm{B}$, organic fertilizer \\
\hline & Intensity & Very intensive \\
\hline (5) Protection & Plant pest & Many kinds of pest presents \\
\hline \multirow{3}{*}{ (6) Harvesting } & Start to produce & $30 \mathrm{mo}$ \\
\hline & $\begin{array}{l}\text { Production on stable } \\
\text { productivity }\end{array}$ & $8 \mathrm{t}$ seed $\mathrm{ha}^{-1}$ \\
\hline & Edible/non-edible & Edible \\
\hline \multirow{4}{*}{ (7) Palm oil mills } & Production of crude oil & By milling \\
\hline & Value of FFA & $<2$ \\
\hline & Ratio of FFB to crude oil & $21 \%$ \\
\hline & Produced biomass & Empty Fruit Bunch \\
\hline
\end{tabular}

(Continued on next page) 
Table 1. Continued

\begin{tabular}{|l|l|l|}
\hline Input activities & \multicolumn{1}{|c|}{ Component } & \multicolumn{1}{c|}{ Oil palm } \\
\hline (8) Biomass Tank & \multicolumn{1}{|c|}{-} \\
\hline (9) Reactor & Dimension & $\begin{array}{l}900 \mathrm{~mm}(\mathrm{OD}) \times 1000 \mathrm{~mm} \\
\text { (height })\end{array}$ \\
\hline (10) Cyclone & Dimension & $\begin{array}{l}580 \mathrm{~mm}(\mathrm{OD}) \times 1766 \mathrm{~mm} \\
\text { (height })\end{array}$ \\
\hline$(11)$ Wet Scrubber & Dimension & $\begin{array}{l}5 \mathrm{tubes} \times 300 \mathrm{~mm}(\mathrm{OD}) \times 1750 \\
\mathrm{~mm}(\text { long }) \times 1300 \mathrm{~mm}(\mathrm{height})\end{array}$ \\
\hline$(12)$ Filter 1 & Dimension & $\begin{array}{l}700 \mathrm{~mm}(\text { long }) \times 700 \mathrm{~mm} \\
\text { (wide }) \times 700 \mathrm{~mm}(\text { height })\end{array}$ \\
\hline (13) Blower & Power & $1 \mathrm{HP}$ \\
\hline (14) Filter 2 & Dimension & $\begin{array}{l}700 \mathrm{~mm}(\text { long }) \times 700 \mathrm{~mm} \\
(\text { wide }) \times 700 \mathrm{~mm}(\text { height })\end{array}$ \\
\hline (15) Gas Engine & Capacity & $50 \mathrm{KW}$ \\
\hline (16) User & Distribution using cable & $2 \mathrm{~km}$ \\
\hline
\end{tabular}

Table 2. Mass and energy flow for $1 \mathrm{kWh}$ electricity of empty fruit bunch biomass from palm oil mill.

\begin{tabular}{|c|c|c|c|}
\hline Process & Mass and Energy & Unit & Quantity \\
\hline \multirow[t]{2}{*}{ (1) Land clearing } & Herbicide & $\mathrm{kg}$ & $2.90 \mathrm{E}-05$ \\
\hline & Diesel for toppling \& clearing & 1 & $1.61 \mathrm{E}-05$ \\
\hline \multirow[t]{11}{*}{ (2)Seedling } & Fungicide & $\mathrm{kg}$ & $1.85 \mathrm{E}-05$ \\
\hline & Insecticide & $\mathrm{kg}$ & $1.27 \mathrm{E}-06$ \\
\hline & Meister of Fertilizer & $\mathrm{kg}$ & $1.93 \mathrm{E}-06$ \\
\hline & Chemical fertilizer/Urea $0.2 \%$ & 1 & $2.68 \mathrm{E}-05$ \\
\hline & Organic fertilizer & $\mathrm{kg}$ & $8.12 \mathrm{E}-05$ \\
\hline & TSP/SP36 & $\mathrm{kg}$ & $2.55 \mathrm{E}-06$ \\
\hline & Muriate of Potash (K) & $\mathrm{kg}$ & $2.20 \mathrm{E}-08$ \\
\hline & Dolomite & $\mathrm{kg}$ & $4.39 \mathrm{E}-08$ \\
\hline & N-P-K-Mg (mixing) & $\mathrm{kg}$ & $1.48 \mathrm{E}-05$ \\
\hline & Electricity for water pump & $\mathrm{kWh}$ & $6.38 \mathrm{E}-04$ \\
\hline & Pesticide & $\mathrm{kg}$ & $4.37 \mathrm{E}-06$ \\
\hline Transportation & Diesel fuel for truck $5 \mathrm{t}$ & 1 & $1.17 \mathrm{E}-04$ \\
\hline \multirow[t]{4}{*}{ (3) Planting } & TSP/SP36 & $\mathrm{kg}$ & $2.30 \mathrm{E}-04$ \\
\hline & Organic fertilizer & $\mathrm{kg}$ & $3.87 \mathrm{E}-06$ \\
\hline & Rock Phosphate (RP) & $\mathrm{kg}$ & $2.91 \mathrm{E}-05$ \\
\hline & $\mathrm{KCl}$ & & - \\
\hline (4) Fertilization & Urea & $\mathrm{kg}$ & $4.41 \mathrm{E}-03$ \\
\hline \multirow{10}{*}{ For $5 \mathrm{yr}$} & TSP/SP36 & $\mathrm{kg}$ & $1.78 \mathrm{E}-03$ \\
\hline & Rock Phosphate (RP) & $\mathrm{kg}$ & $3.67 \mathrm{E}-03$ \\
\hline & Sulphate Ammonia (ZA) & $\mathrm{kg}$ & $1.09 \mathrm{E}-03$ \\
\hline & Muriate of Potash (K) & $\mathrm{kg}$ & $4.82 \mathrm{E}-03$ \\
\hline & Kieserite $\left(\mathrm{MgSO}_{4}\right)$ & $\mathrm{kg}$ & $2.84 \mathrm{E}-03$ \\
\hline & HGF-B (HGF-Borate) & $\mathrm{kg}$ & $1.83 \mathrm{E}-04$ \\
\hline & $\mathrm{CuSO}_{4}$ & $\mathrm{~kg}$ & $8.72 \mathrm{E}-05$ \\
\hline & $\mathrm{ZnSO}_{4}$ & $\mathrm{~kg}$ & $3.78 \mathrm{E}-05$ \\
\hline & LSD & $\mathrm{kg}$ & $1.31 \mathrm{E}-03$ \\
\hline & Organic fertilizer & $\mathrm{kg}$ & - \\
\hline
\end{tabular}

(Continued on next page) 
Table 2. Continued

\begin{tabular}{|c|c|c|c|}
\hline Process & Mass and Energy & Unit & Quantity \\
\hline (5)Protection & Insecticide & $\mathrm{kg}$ & $6.35 \mathrm{E}-05$ \\
\hline \multirow[t]{2}{*}{ For $5 \mathrm{yr}$} & Pesticide & $\mathrm{kg}$ & $7.53 \mathrm{E}-05$ \\
\hline & $\begin{array}{l}\text { Diesel for sprayer \& } \\
\text { fogging }\end{array}$ & 1 & $1.32 \mathrm{E}-05$ \\
\hline (6) Harvesting & $\begin{array}{l}\text { Diesel fuel for truck } \\
10 \mathrm{t}\end{array}$ & 1 & $1.20 \mathrm{E}-04$ \\
\hline \multirow[t]{11}{*}{ (7) Palm oil mill } & Electricity from grid & $\mathrm{kWh}$ & $1.05 \mathrm{E}-03$ \\
\hline & Steam consumption & $\mathrm{kg}$ & $1.43 \mathrm{E}-03$ \\
\hline & Water consumption & $\mathrm{m}^{3}$ & $2.11 \mathrm{E}-05$ \\
\hline & PAC & $\mathrm{kg}$ & $6.37 \mathrm{E}-07$ \\
\hline & Flocculants & $\mathrm{kg}$ & $2.20 \mathrm{E}-09$ \\
\hline & $\mathrm{NaOH}$ & $\mathrm{kg}$ & $5.49 \mathrm{E}-07$ \\
\hline & $\mathrm{H}_{2} \mathrm{SO}_{4} / \mathrm{HCl}$ & $\mathrm{kg}$ & $5.49 \mathrm{E}-07$ \\
\hline & Tannin concéntrate & $\mathrm{kg}$ & $2.42 \mathrm{E}-07$ \\
\hline & $\begin{array}{l}\text { Poly Perse BWT } \\
302\end{array}$ & $\mathrm{~kg}$ & $2.42 \mathrm{E}-07$ \\
\hline & Alkali BWT 402 & $\mathrm{~kg}$ & $2.20 \mathrm{E}-07$ \\
\hline & Fiber/Shell & $\mathrm{kg}$ & $6.86 \mathrm{E}-04$ \\
\hline Transportation & Diesel fossil fuel & 1 & $1.13 \mathrm{E}-04$ \\
\hline (8) Biomass Tank & Empty Fruit Bunch & $\mathrm{kg}$ & $1.60 \mathrm{E}-00$ \\
\hline (9) Reactor & - & - & - \\
\hline (10) Cyclone & - & - & - \\
\hline $\begin{array}{l}\text { (11) Wet tar } \\
\text { Scrubber }\end{array}$ & $\begin{array}{l}\text { Electricity for water } \\
\text { pump } \\
\text { Water consumption }\end{array}$ & $\begin{array}{c}\mathrm{kWh} \\
\mathrm{m}^{3}\end{array}$ & $\begin{array}{l}9.50 \mathrm{E}-03 \\
7.13 \mathrm{E}-02\end{array}$ \\
\hline (12) Filter 1 & Zeolite & $\mathrm{kg}$ & $3.30 \mathrm{E}-04$ \\
\hline (13) Blower & Electricity & $\mathrm{kWh}$ & $1.19 \mathrm{E}-02$ \\
\hline (14) Filter 2 & Glass wool & $\mathrm{kg}$ & $9.90 \mathrm{E}-06$ \\
\hline (15) Gas Engine & $\begin{array}{l}\text { Lead acid battery } \\
\text { Lubricant oil } \\
\text { Radiator coolant } \\
\text { Filter }\end{array}$ & $\begin{array}{c}\text { Unit } \\
1 \\
1 \\
\text { Unit }\end{array}$ & $\begin{array}{l}1.08 \mathrm{E}-05 \\
1.32 \mathrm{E}-04 \\
1.39 \mathrm{E}-03 \\
2.20 \mathrm{E}-05\end{array}$ \\
\hline (16) User & Cable connector & $\mathrm{km}$ & $2.00 \mathrm{E}-00$ \\
\hline
\end{tabular}

\subsection{Life Cycle Impact Assessment}

The result of this study was the Life Cycle Impact Assessment of electricity production through biomass power plant system. This study consist of cradle to grave system boundary, which calculated the environmental impact of the raw material acquisition to the user and the end of life. Total GHG emission was $0.152 \mathrm{~kg} \mathrm{CO}_{2}$-eq $\mathrm{kWh}^{-1}$. This study result showed that the gas engine was the significant number of GHG emission followed by fertilizing, blower, and wet tar scrubber. Biomass Tank, Reactor and Cyclone was the lowest GHG emission as this stage has zero-emission in the process. The LCIA result of GHG emission impact category as presented in Figure 3. 


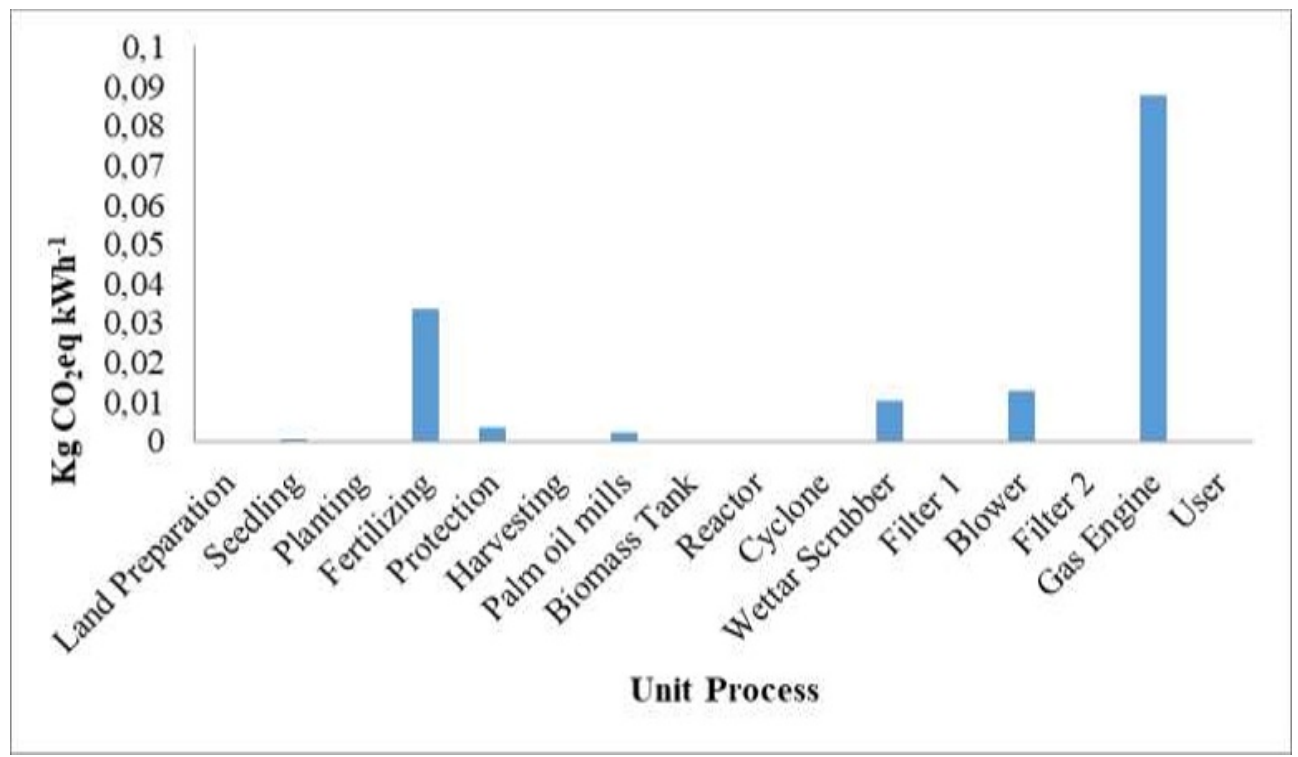

Fig. 3. LCIA result of GHG emission of Biomass Power Plant

The total of GHG emission is lower than fossil fuel, coal, and natural gas, but higher than nuclear, hydropower, and geothermal as reported by Siregar et al. [12]. Compared to diesel fuel, GHG emission has a potential reduction of up to $49 \%$ and if we compared to coal, the GHG emission has potential reduction of up to $45.1 \%$. The utilization of empty fruit bunch from palm oil for electricity production can reduce the environmental impact of palm oil production due to waste utilization and the number of GHG emission-reducing from palm oil production reach up to $25 \%$.

The biomass power plant system has many advantages compared to other power plant systems. For empty fruit bunch biomass itself, it has lower GHG emission compared to other biomass power generation and even it has much lower GHG emission compared to average GHG emission of the various power plant system. Biomass power plant from empty fruit bunch has higher GHG Emission compared to various renewable energy such as nuclear energy, wind energy, ocean energy, hydropower, geothermal energy, concentrated solar power, photovoltaics, biopower, hydropower (Indonesia), and geothermal energy (Indonesia), however, it has much lower of GHG emission compared to powerplant from coal, oil, natural gas, diesel mix gas, and steam mix gas. The result of GHG emission from a various power plants in Indonesia also showed that biomass power plant from an empty fruit bunch has lower GHG emission compared to the powerplant system which has only gate to gate system boundary as presented in Figure 4. 


\section{Potential for Global Warming}

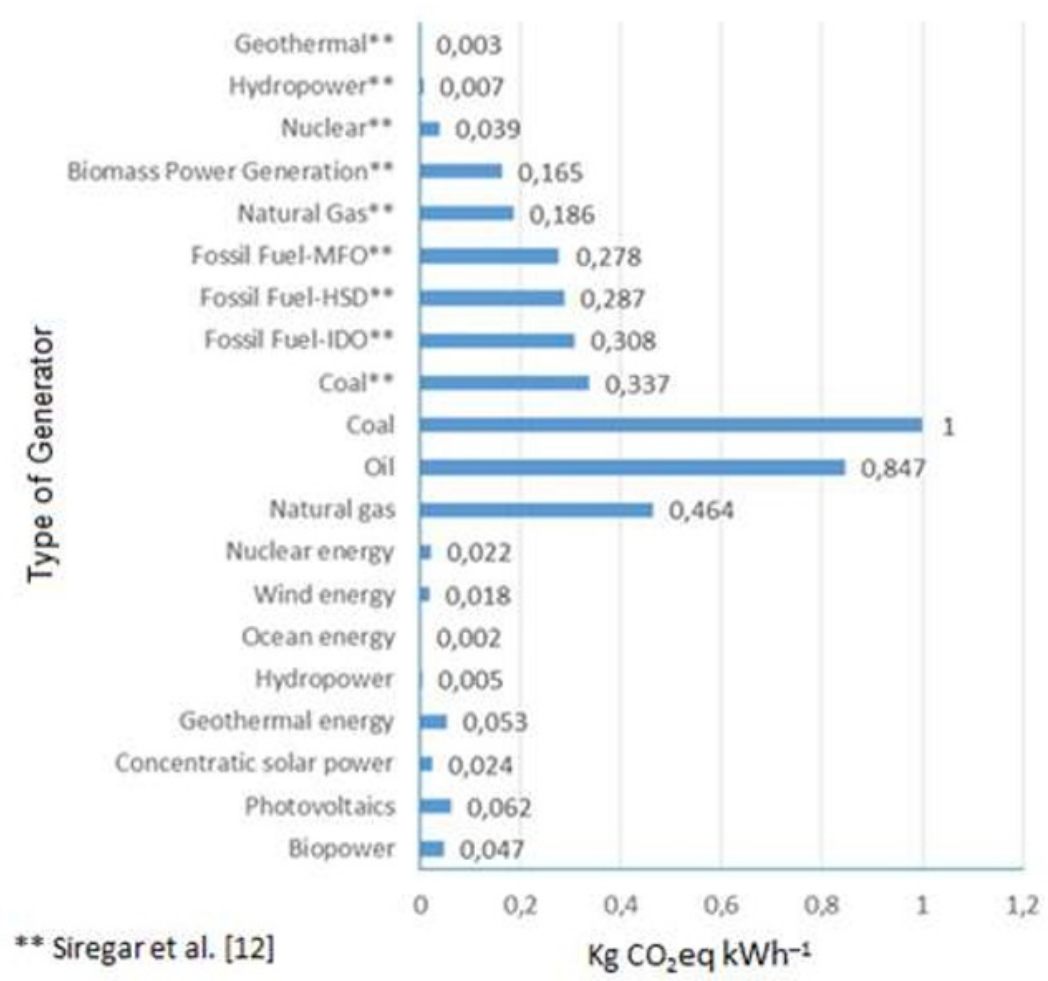

Fig. 4. The GHG emission of a various power plant system in Indonesia [12].

Biomass from an empty bunch also has benefits in reducing the GHG emission from palm oil production due to the utilization of waste biomass from palm oil production. Palm oil production has a significant environmental impact related to GHG emission released from the CPO production. The number of GHG emission released reach up to $1869.39 \mathrm{~kg}$ $\mathrm{CO}_{2}$-eq $\mathrm{t}^{-1} \mathrm{CPO}$ [12]. This number was much higher if the emission is charged only to the CPO production. Even though this should be allocated to the various co-product which have potentially been utilized during the palm oil life cycle. Studies reported that from palm oil production it has various co-product during its life cycle. The research reported that processing $1 \mathrm{t}$ of fresh fruit bunch (FFB) produces around $25 \%$ or $254.7 \mathrm{~kg}$ of empty fruit bunch as well as $240.4 \mathrm{~L}$ of POME [13]. $1 \mathrm{~m}^{3}$ of POME treated using the ponding system for anaerobic digestion produces $28 \mathrm{~m}^{3}$ of biogás, which is comprised of $65 \%$ methane and $30 \% \mathrm{CO}_{2}$ [14]. It was assumed that $28 \%$ of POME can be utilized as biogas. This research also showed that $25 \%$ of the empty fruit bunch can be utilized as electricity production. During the electricity production from biomass, it also produces $5 \%$ husk charcoal that also can be allocated as a co-product for land application. Figure 1 shown that palm oil has many derivative products, such as palm oil, biomass, biogas, palm kernel oil and etc. So far the impact calculation has always been charged to palm oil itself. Whereas, if all palm oil derivative products are included in the calculation, the environmental impact caused by palm oil processing will be smaller. The biomass utilization from palm oil plantation for electricity is needed to be investigated further. It is related to the gasification system and tools which is less easy maintaining. 


\section{Conclusion}

The electricity production from empty fruit bunch biomass has been considered as climatefriendly power plant system due to its GHG emission released lower than other powerplant systems. Biomass power plant through the gasification system as conducted in this research produced GHG emission $0.152 \mathrm{~kg} \mathrm{CO}_{2}$-eq $\mathrm{kWh}^{-1}$. Gas engine stage was the highest GHG emission contributor during the life cycle which has produced $0.087 \mathrm{~kg} \mathrm{CO}_{2}$-eq kWh${ }^{-1}$ while biomass tank, cyclone, and reactor have zero-emission. Palm oil plantation has various co-product to be utilized and potentially reducing GHG emissions from palm oil production. From this research, the utilization of fruit empty bunch biomass can reduce the GHG emission of palm oil by up to $25 \%$.

This research was supported by DGHE, Ministry of Research, Technology, and Higher Education, under PPTI-Program Pengembangan Teknologi Industri [Industrial Technology Development Program] Scheme with number SK No. 5/E/KPT/2019.

\section{References}

1. Department of Energy and Mineral Resources (DESDM). BluePrint Pengelolaan Energi Nasional, (Workshop Sosialisasi Blue Print Pengelolaan Energi Nasional (2006).p.73.

https://www.esdm.go.id/assets/media/content/Blueprint PEN tgl 10 Nop 20 07.pdf

2. E. Hambali, M. Rivai, The Potential of Palm Oil Waste Biomass in Indonesia in 2020 and 2030.IOP Conference Series: Earth and Environmental Science. 65,012050(2017) https://iopscience.iop.org/article/10.1088/1755-1315/65/1/012050

3. Y.S. Pradana, A. Kurniawan, A. Budiman, Bio-oil Derived from Indonesian Oil Palm Empty Fruit Bunch (EFB) using Middle-scale Slow Pyrolysis. Proceeding the International Oil Palm Conference, Bali, Indonesia (2014) https://www.researchgate.net/publication/315483102_Biooil_Derived_from_Indonesian_Oil_Palm_Empty_Fruit_Bunch_EFB_using_Middlescale_Slow Pyrolysis

4. K. Siregar, Sholihati, Syafriandi, Int. Journal of Engineering Research and Application, 6:09-16 (2016) https://www.researchgate.net/publication/291336260 The Potential Applicati on_of_Gasification_for_Biomass_Power_Generation_in_Isolated_Area_from National Electricity Company in Indonesia

5. A.H.R. Aljuboori. International Journal of Biomass \& Renewables. 13-18 (2013) link: https://www.researchgate.net/publication/281510401_Oil_palm_biomass_resi due in Malaysia Availability and sustainability

6. S.H. Shuit, K.T. Tan , K.T. Lee, A.H. Kamaruddin. Energy. 34,9:1225-1235(2009) https://www.researchgate.net/publication/223659992_Oil_palm_biomass_as_a _sustainable_energy_source_A_Malaysia_case_study

7. A. Molino, S. Chianese, D. Musmarra. Journal of Energy Chemistry, 25,1:10-25 (2016)

https://www.sciencedirect.com/science/article/abs/pii/S2095495615001102

8. R. Rauch, J. Hrbek, H. Hofbauer H. Wiley Interdisciplinary Reviews: Energy Environment. 3,4:343-362(2013) https://www.researchgate.net/publication/259543643 Biomass Gasification f or_Synthesis_Gas_Production_and_Applications_of_the_Syngas 
9. L.E. Taba, M.F. Irfan, W.A.M.W. Daud, M.H. Chakrabarti. 16,8:5584-5596 (2012) https://www.sciencedirect.com/science/article/abs/pii/S1364032112004029

10. J.A. Ruiz, M.C. Juarez, M.P. Morales, P. Munoz, M.A. Mendivil, Renewable and Sustainable Energy Reviews, 18,174-183 (2013)

https://www.sciencedirect.com/science/article/abs/pii/S1364032112005631

11. SRREN (The Spesial Report on Renewable Energy Resource and Climate Change Mitigation) IPCC Working Group. Renewable energy source and climate change mitigation, summary for policymakers and technical summary, IPCC (2011) https://archive.ipcc.ch/pdf/special-reports/srren/SRREN FD SPM final.pdf

12. K. Siregar, R. Alamsyah, I. Ichwana, S. Sholihati, S. Tou, N.C. Siregar, The Integration of Gasification Systems with Gas Engine by Developing Wet Tar Scrubbers and Gas Filter to Produce Electrical Energy from Biomass, Matec. Web. Conference. 164,01024(2018). https://www.matecconferences.org/articles/matecconf/abs/2018/23/matecconf_icesti2018_01024/ matecconf icesti2018 01024.html

13. T.W. Koura, V. Kindomihou, G. Dagbenonbakin, M. Janssens, B. Sinsin. African Journal of Agricultural Research. 11,19:1787-1796 (2016).

https://www.researchgate.net/publication/303291342_Quantitative_assessmen t_of_palm_oil_wastes_generated_by_mills_in_Southern_Benin

14. C.W. Puah, Y.M. Choo, S.H. Ong, American Journal of Applied Science. 10,11:13511355 (2013).

https://www.researchgate.net/publication/282592962 Production of Palm Oi 1 with methane avoidance at Palm Oil Mill A case study of cradle-togate life cycle assessment/link/57fc695b08ae51472e7e8878/download 